\title{
Significance of limnetic organic aggregates (lake snow) for the sinking flux of particulate organic matter in a large lake
}

\author{
Hans-Peter Grossart*, Meinhard Simon
}

Limnological Institute, University of Constance, PO Box 5560, D-78434 Konstanz, Germany

\begin{abstract}
The abundance, composition and bacterial colonization of macroscopic organic aggregates (lake snow) were studied from March until November 1993 in Lake Constance, Germany. In addition, the concentration of particulate organic carbon (POC) and the amount, composition, and bacterial colonization of particulate matter (PM) collected in a sediment trap deployed at $50 \mathrm{~m}$ were investigated. The seasonal and vertical dynamics of lake snow and of sinking PM were closely linked to those of phytoplankton blooms in spring, summer, and fall and to sedimentation losses of zooplankton during the clear-water phase. POC in lake snow comprised between 0.15 and $28 \%$ of total POC in the surrounding water. On the other hand, sinking losses of POC bound in lake snow as estimated from the abundance, POC content and potential sinking rates of lake snow comprised much higher percentages, indicating the significance of these aggregates for the $\mathrm{POC}$ sinking flux. Particulate combined amino acids comprised 8 to $51 \%$ of lake snow POC and were turned over in $<20 \mathrm{~h}$ as determined from high rates of aminopeptidase activity. A rapid release of dissolved amino acids from sediment trap material into the surrounding water was shown experimentally indicating that the rapid POM decomposition in the aphotic zone leads to a supply of dissolved organic matter (DOM) to planktonic bacteria at this depth. However, in the same type of experiments we found that dissolved amino acids were taken up by the bacteria associated with the settled material when it was deprived of labile organic substrates. This finding complicates the 1-way concept of bacterially mediated interactions between POM and DOM in aquatic environments.
\end{abstract}

KEY WORDS: Lake snow Lake Constance - Sinking flux - POM Amino acids Sediment trap . Aminopeptidase - POM decomposition

\section{INTRODUCTION}

The significance of macroscopic organic aggregates in pelagic marine ecosystems (marine snow) for the cycling and vertical flux of elements and energy has been studied extensively (see reviews by Fowler \& Knauer 1986, Alldredge \& Silver 1988). The dense microbial colonization of marine snow (Silver \& Alldredge 1981, Davoll \& Silver 1986, Riebesell 1991) leads to a rapid release and recycling of labile dis-

\footnotetext{
- Present address: Institute for Chemistry and Biology of the Marine Environment, PO Box 2503, D-26111 Oldenburg, Germany.E-mail: hgrossart@icbm.uni-oldenburg.de
}

solved organic and inorganic matter (Shanks \& Trent 1979, Pomeroy et al. 1984, Smith et al. 1992, Hoppe et al. 1993). In addition, large, fast-sinking aggregates are an important component of the vertical flux of particulate organic matter (POM; Fowler \& Knauer 1986, Alldredge \& Silver 1988) and dominate vertical transport processes in the mesopelagic zone and below (Bishop et al. 1980, Honjo et al. 1984).

Studies of the POM sinking flux with regard to its size distribution in lakes have shown that, as in marine systems, larger particles contribute more to the sinking flux than smaller ones (Stabel 1985, Bloesch \& Bürgi 1989, Weilenmann et al. 1989). Aggregation increases particle size and thus settling velocity, accelerates particle removal, and reduces particle concentrations in 
the water column (Eisma 1993). In lakes in which POM production is dominated by phytoplankton the POM sinking flux is related to phytoplankton dynamics but to a variable degree depending on the composition of the phytoplankton community and its potential for settling (Stabel 1985). Zooplankton can affect sedimentation positively by packaging algae into fecal pellets and by molts and carcasses, and negatively by phytoplankton grazing (Simon et al. 1993), Even though the POM sinking flux in general is positively correlated to the productivity of pelagic ecosystems, pronounced differences exist between lacustrine and marine environments (Aksnes \& Wassmann 1993, Baines et al. 1994). The existence of detrital particles in lakes has been shown by filtration or sediment trap studies (e.g. Stabel 1985, Weilenmann et al, 1989) but the significance of fragile aggregates such as lake snow (Grossart \& Simon 1993, Grossart et al. 1997) for vertical transport processes has not yet been studied. Because lake snow plays a similar role in lacustrine plankton dynamics to that of marine snow in neritic environments it is important to study its significance for the sinking flux in lakes.

During sinking, particles and aggregates are decomposed and modified chemically. This degradation has been inferred in oceanic environments from size fractionation and sediment trap studies by an increasing $\mathrm{C}: \mathrm{N}$ ratio, a loss in labile organic compounds with depth, and the increasing dominance of bacterial hydrolytic activities over substrate uptake (Wakeham et al. 1984, Cowie \& Hedges 1992, Hoppe et al. 1993). The microbial decomposition of marine snow found in an experimental set up (Smith et at. 1992) demonstrated rapid release of dissolved amino acids and turnover of particulate combined amino acids (PCAA). However, the microbial decomposition of lake snow has not yet been studied in direct relation to the decomposition of sinking POM. It is attractive to examine these processes in a lake because frequent collection of lake snow by SCUBA and by short-term deployments of sediment traps during a given time period is much more convenient and requires less logistics than in the sea.

We investigated the seasonal dynamics of the formation and composition of lake snow and its microbial decomposition in combination with the decomposition of the sinking POM in Lake Constance (Bodensee, Germany). In 2 other papers the results of the formation (Grossart et al. 1997) and the microbial decomposition of lake snow (Grossart \& Simon 1998, in this issue) are presented. In this paper we report on the seasonal dynamics and the microbial turnover of PCAA on lake snow and particulate matter (PM) collected in sediment traps in relation to dynamics of the POM.

\section{MATERIALS AND METHODS}

Study site and sampling. Lake Constance is a warmmonomictic large and deep lake $\left(47^{\circ} 40^{\prime} \mathrm{N}, 9^{\circ} 15^{\prime} \mathrm{E}\right.$ ) with a surface area of $571 \mathrm{~km}^{2}$ and a maximum depth of $254 \mathrm{~m}$. During the last decade the lake's phosphorus loading decreased by ca 70\% (Güde et al. 1998), resulting in its mesotrophic status today. The study was performed in the Überlinger See, the northwestern part of Lake Constance, at a central station $(147 \mathrm{~m}$ deep) which is influenced only little by the Rhine river current. Water samples were collected on board the RV 'Robert Lauterborn' with a 91 van Dorn bottle at $3,6,10,15,25,30,40$, and $50 \mathrm{~m}$. Aggregates were enumerated and collected in situ at 6,15 , and $25 \mathrm{~m}$.

Enumeration of macroscopic organic aggregates. Throughout the entire growing season in 1993 the abundance of lake snow ( $3 \mathrm{~mm}$ or larger) was determined by numerous SCUBA dives in 2 different ways: (1) at low concentrations $\left(<5\right.$ agg. $\left.~^{-1}\right)$ aggregates were counted visually in a volume of $1 \mathrm{l}$ defined by a wire cube with at least 50 replicates; (2) at high concentrations (>5 agg. $\mathrm{l}^{-1}$ ) aggregates were counted on 5 replicate photographs taken at each depth (Grossart \& Simon 1993). The comparison of both methods gave similar results when the abundance was approximately 10 agg. $\mathrm{l}^{-1}$.

During the same SCUBA dives individual lake snow was collected in $6 \mathrm{ml}$ open-ended plastic syringes (Gotschalk \& Alldredge 1989) and remained in the syringes in a cooling box for $<2 \mathrm{~h}$ until further analysis in the lab.

Sinking velocity of aggregates. Individual aggregates were carefully transferred into a graduated 11 glass cylinder filled with the surrounding water at in situ temperature and the time an aggregate settled through a distance of $30 \mathrm{~cm}$ was recorded. Possible convection of the fluid was detected by methylene blue staining (Grossart \& Simon 1993). The measured settling velocities have to be considered as potential rates since the sinking of aggregates inside the cylinder was only controlled by gravitational forces. Other parameters, e.g. turbulent shear or upwelling affecting the settlement of lake snow in situ, were excluded.

Sedimentation. Sedimentation of suspended matter was measured in cylindrical sediment traps which were $100 \mathrm{~cm}$ high and $10 \mathrm{~cm}$ in diameter (Bloesch \& Burns 1980). Four traps were deployed at $50 \mathrm{~m}$ depth and carefully retrieved every 3 to $4 \mathrm{~d}$. We did not poison the traps because of the short deployment time and because we measured bacterial activities on the settled material (see below). After retrieval of the traps part of the water was drained, the collected material homogenously mixed with the remaining water, and the resulting suspension (ca 1 l) filtered through a 
plankton net (300 $\mu \mathrm{m}$ pore size) to remove the large zooplankton. The collected PM was kept refrigerated in darkened bottles until further analysis.

Dry weight (DW), particulate organic carbon (POC), and CHN analysis. Water samples, lake snow, and sediment trap material were filtered through precombusted and preweighed $\left(W_{0}\right)$ glass microfibre filters (1 $\mu \mathrm{m}$ pore size, Schleicher \& Schüll, Germany). Thereafter filters were dried at $110^{\circ} \mathrm{C}$ for $1 \mathrm{~h}$ and weighed again $\left(W_{1}\right)$. The dry weight of the PM was determined as $W_{1}-W_{0}$. Filters were then combusted at $550^{\circ} \mathrm{C}$ for $2 \mathrm{~h}$ and weighed again $\left(W_{2}\right)$. POM was calculated as $W_{1}-W_{2}$. POC was estimated as $50 \%$ of POM (Jones 1979). Total $C$ and the $C: N$ ratio of $P M$ were measured by $\mathrm{CHN}$ analysis (Carlo Erba). For measurements of lake snow POC, 10 individual aggregates were pooled and treated as described above.

Amino acid analysis. Dissolved free (DFAA) and combined amino acids (DCAA) were determined in triplicate by high performance liquid chromatography (HPLC) after precolumn derivatization with o-phthaldialdehyde according to Simon \& Rosenstock (1992). Samples were prefiltered through a $0.2 \mu \mathrm{m}$ tuffrin filter (Gelman Acrodisc) with low protein binding capacity. DFAA were measured directly. For the analysis of lake snow PCAA, 10 aggregates were pooled in $1 \mathrm{ml}$ of double-distilled water in triplicate. Samples of DCAA and PCAA were hydrolyzed prior to analysis in double-distilled $6 \mathrm{~N} \mathrm{HCl}$ for $20 \mathrm{~h}$ at $110^{\circ} \mathrm{C}$. Amino acid oxidation due to high nitrate concentrations was pre-

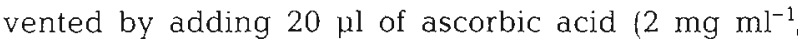
stock solution) prior to hydrolysis.

Bacterial numbers. Bacteria were counted after DAPI staining by epifluorescence microscopy (Porter \& Feig 1980). Bacteria were removed from lake snow and sediment trap material by ultrasonic treatment in 2 mM Na-pyrophosphate (Velji \& Albright 1986) and then filtered onto $0.2 \mu \mathrm{m}$ Nuclepore membranes. Biomass of bacteria on lake snow and on PM in sediment traps was estimated by assuming a volume of $0.15 \mu \mathrm{m}^{3}$ cell $^{-1}$ and $53 \mathrm{fg}$ carbon cell $^{-1}$ (Grossart \& Simon 1993).

Aminopeptidase assay. Bacterial aminopeptidase activity was measured after incubation with L-leucine-4methyl-7-coumarinylamide (Leu-MCA, Fluka, Switzerland) by a slightly modified protocol of Hoppe et al. (1988). Concentration kinetics yielded saturating substrate concentrations of 250 to $500 \mu \mathrm{M}$ (final conc.) for aminopeptidase activity on lake snow and on sediment trap material throughout the year. Incubation of triplicates and a control was performed for $1 \mathrm{~h}$ at in situ temperature in the dark. Fluorescence readings were done with a Kontron fluorometer (SFM 25) at $380 \mathrm{~nm}$ excitation and $440 \mathrm{~nm}$ emission.

Changes in amino acid concentration above sediment trap material over time. Sediment traps were deployed at $30 \mathrm{~m}$ depth for $1 \mathrm{~d}$ and closed with a lid by SCUBA divers. Subsamples of the overlying water were periodically withdrawn for $9 \mathrm{~h}$ by SCUBA using syringes through silicon septa $1,3.5$, and $6 \mathrm{~cm}$ above the bottom of the trap. To determine changes in amino acid concentration under simulated in situ conditions the closed sediment traps were retrieved and carefully transferred to the lab to a dark incubation chamber $\left(4^{\circ} \mathrm{C}\right)$ without disturbing the collected material. There, subsamples for amino acid analyses were withdrawn periodically for 65 to $75 \mathrm{~h}$. Amino acid analyses were done as described above.

Bacterial growth. Bacterial production was measured by ${ }^{14} \mathrm{C}$-leucine (Leu) incorporation according to Simon \& Azam (1989). One ml of sediment trap material was suspended in $5 \mathrm{ml}$ of sample water and incubated with Leu (312 $\mathrm{mCi} \mathrm{mmol}^{-1}$, Amersham) at a final concentration of $60 \mathrm{nM}$. The incubation of triplicate samples and a formalin-killed control ( $2 \%$ final conc.) was performed in the dark at in situ temperature and stopped after $1 \mathrm{~h}$ with formalin. Samples were filtered onto a $0.45 \mu \mathrm{m}$ cellulose nitrate filter, extracted for 5 min with $5 \%$ ice-cold trichloroacetic acid and radioassayed thereafter. Incorporation of Leu was converted into carbon produced via bacterial protein production (BPP-C) according to Simon \& Azam (1989) and assuming an isotope dilution factor of 2 for Leu. Bacterial growth rates were calculated from BPP-C rates and bacterial biomass assuming exponential growth.

\section{RESULTS}

\section{Seasonal dynamics of plankton and lake snow}

The seasonal patterns of the plankton dynamics in Lake Constance were reflected in the distribution of POC (Fig. 1). The phytoplankton spring bloom with its maximum at the end of April exhibited highest POC concentrations of 1.6 to $2 \mathrm{mg} \mathrm{C}^{-1}$ near the surface and ca $1 \mathrm{mg} \mathrm{Cl}^{-1}$ even as far down as $30 \mathrm{~m}$. It was followed by the clear-water phase in June which was characterized by low POC concentrations but high numbers of cladoceran zooplankton. In July and August a phytoplankton summer bloom developed with POC concen-

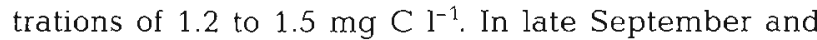
throughout October an autumnal near-surface bloom of colony-forming cyanobacteria became established which was reflected only weakly in enhanced POC concentrations. The phytoplankton bloom in spring consisted of cryptophytes and small diatoms and that in summer mainly of large diatoms.

Abundances of lake snow were closely related to the seasonal plankton dynamics. Phytoplankton blooms resulted in enhanced numbers of aggregates from $5 \mathrm{I}^{-1}$ 


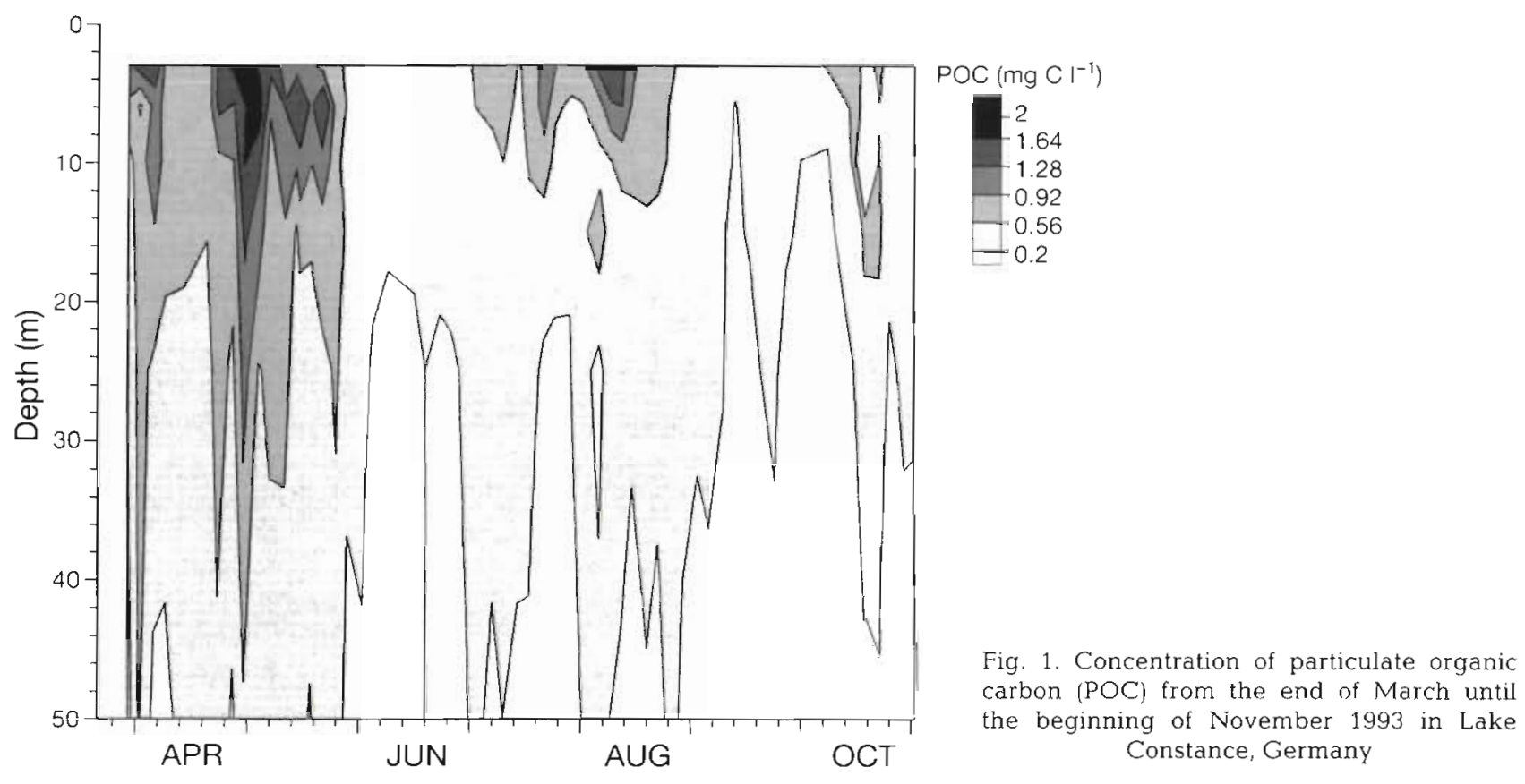

at the spring bloom to $25-50 \mathrm{l}^{-1}$ in summer and fall. During the clear-water phase $<1$ to 7 agg. $\mathrm{l}^{-1}$ were recorded which were dominated by molts and carcasses of zooplankton (for further details see Grossart et al. 1997).

The size of aggregates ranged between 3 and $20 \mathrm{~mm}$ in diameter. The sinking velocities of aggregates varied according to their size, form, and composition and were 5.2 to $25.3 \mathrm{~m} \mathrm{~d}^{-1}$ (Table 1). Highest sinking rates were recorded for aggregates of large diatoms at the end of July and in August and lowest for cyanobacterial aggregates in October.

\section{Fractions of POC and PCAA on lake snow}

Aggregates of phytoplanktonic and zooplanktonic origin contained 1 to $10 \mu \mathrm{g}$ POC agg.- during the spring bloom and during the cyanobacterial bloom in fall (Table 2, which presents only values at $25 \mathrm{~m}$ on

Table 1. Sinking velocities of lake snow shown as mean and standard deviation (SD) of 10 replicate measurements

\begin{tabular}{|c|c|c|c|}
\hline \multirow[t]{2}{*}{ Date 1993} & \multirow{2}{*}{$\begin{array}{l}\text { Type of } \\
\text { aggregate }\end{array}$} & \multicolumn{2}{|c|}{ Sinking velocity $\left(\mathrm{m} \mathrm{d}^{-1}\right.$ ) } \\
\hline & & Mean & $\mathrm{SD}$ \\
\hline 24 April & Small diatoms & 11.7 & \pm 2.1 \\
\hline 19-31 May & $\begin{array}{l}\text { Zooplankton molts } \\
\text { and carcasses }\end{array}$ & 12.0 & \pm 2.4 \\
\hline 9 June & Green algae & 17.2 & \pm 5.3 \\
\hline 22-29 July & Large diatoms & 25.3 & \pm 7.4 \\
\hline 16-30 August & Molts and diatoms & 20.1 & \pm 3.6 \\
\hline 11 October & Cyanobacteria & 5.2 & \pm 1.3 \\
\hline
\end{tabular}

dates when the sinking velocity was measured). On the basis of the abundance of lake snow and its individual POC content we calculated the fraction of POC per liter bound in lake snow as percent of total POC. Throughout our study it varied from 0.15 to $28 \%$ (Fig. 2) and was $>20 \%$ at the early spring bloom when a special type of aggregate dominated by diatoms occurred at the surface and during the cyanobacterial bloom in September and October. During the rest of the season the fraction of POC on aggregates generally increased with depth and reached highest values of 7 to $9 \%$ at $25 \mathrm{~m}$.

Qn several occasions from June to October we determined the PCAA content of lake snow. It varied from 1.2 to $4.3 \mathrm{nmol}$ amino acid equivalents agg. $^{-1}$ which translates into 0.07 to $0.26 \mu \mathrm{g}$ PCAA-C agg. ${ }^{-1}$ assuming $60 \mathrm{~g} \mathrm{C} \mathrm{mol}^{-1}$ amino acid. This amount constituted 8 to $51 \%$ of POC on aggregates. Highest proportions occurred on cyanobacterial aggregates in fall whereas they were 25 to $30 \%$ during the summer bloom. The C:N ratio of lake snow PCAA was 3.4 to 5.5 throughout the season. Comparisons to the PCAA composition of total POC showed that PCAAs on aggregates were relatively enriched in aspartic acid, glutamic acid, and serine, whereas they were relatively depleted in arginine, valine, isoleucine, and leucine.

\section{Bacterial colonization and protein turnover on lake snow}

Bacterial abundance varied from 5 to $80 \times 10^{6}$ cells agg. $^{-1}$ depending on the size and type of lake snow. 
Table 2. Lake snow abundance ( $\mathrm{n}=5$ to $50, \mathrm{SD} \leq 10 \%$ ) and $\mathrm{POC}$ per aggregate $(\mathrm{n}=3, \mathrm{SD} \leq 10 \%)$ at $25 \mathrm{~m}$, losses of total POC (\% d $\left.\mathrm{d}^{-1}\right)$ from 0 to $20 \mathrm{~m}$ due to sedimentation, POC losses due to the sinking of aggregates (". $\left.\mathrm{d}^{-1}\right)$, and ratio of POC losses due to sinking aggregates to POC losses due to sedimentation

\begin{tabular}{|lccccc|}
\hline Date 1993 & $\begin{array}{c}\text { Abundance } \\
\left(1^{-1}\right)\end{array}$ & $\begin{array}{c}\text { POC } \\
\left(\mu g \text { C agg. }{ }^{-1}\right)\end{array}$ & $\begin{array}{c}\text { POC loss } \\
(\%)\end{array}$ & $\begin{array}{c}\text { Agg. loss } \\
(\%)\end{array}$ & Agg./POC \\
\hline 24 April & 5 & 2 & 3 & 0.59 & 0.19 \\
19-31 May & 2 & 3 & 2 & 0.48 & 0.24 \\
9 June & 4 & 5 & 3.5 & 4.86 & 1.39 \\
22-29 July & 12 & 3 & 4 & 8.18 & 2.05 \\
16-30 August & 10 & 5 & 4 & 11.11 & 2.78 \\
11 October & 2 & 1 & 1 & 0.14 & 0.14 \\
\hline
\end{tabular}

Highest numbers were found on cyanobacterial aggregates in fall. Aminopeptidase activity on planktonderived lake snow ranged from 0.02 to $1.96 \mu \mathrm{mol} \mathrm{agg}^{-1}$ $\mathrm{h}^{-1}$ with highest rates in the surface film of diatoms in early spring and on cyanobacterial aggregates in October. PCAA turnover times on lake snow calculated as the ratio of PCAA per aggregate over aminopeptidase hydrolysis rate were in general $<20 \mathrm{~h}$ (Grossárt \& Simon 1998).

\section{Sedimentation}

Sedimentation of PM and POC covaried with the seasonal patterns of POC concentration in the upper $20 \mathrm{~m}$ (Figs. 1, 3 \& 4). Highest sedimentation rates of $1.15 \mathrm{~g} \mathrm{C} \mathrm{m}^{-2} \mathrm{~d}^{-1}\left(19 \mathrm{~g} \mathrm{DW} \mathrm{m}^{-2} \mathrm{~d}^{-1}\right)$ were measured $3 \mathrm{~d}$ after the peak of the phytoplankton spring bloom when maximum abundances of lake snow and transparent exopolymer particles (TEP) co-occurred (Logan et al. 1995). A second peak of sedimentation appeared towards the end of the summer bloom in mid-August (Fig. 3). A calcite precipitation event preceded this peak as shown by microscopic detection of calcite crystals in the sediment trap material and a strong increase of total DW settled in late July not reflected by enhanced POC sedimentation (Fig 4). The peak of the POC sedimentation in mid-August followed the peak of the bloom by $4 \mathrm{~d}$ as indicated by chlorophyll a. Enhanced sedimentation at the end of August was not reflected by epilimnetic POC concentrations and was possibly due to advection of water masses from other areas of the lake, e.g. the littoral. Maximum abundances of lake snow during the cyanobacterial bloom were followed by only slightly enhanced sedimentation rates. Daily POC loss rates due to sedimentation during the various blooms were 1 to $3.5 \%$ (Table 2 ). At other times, like in early spring when the lake was not yet stratified and in late fall, losses remained $<1 \%$. The $\mathrm{C}: \mathrm{N}$ ratio of the sediment trap material during and after the sedimentation events varied from 5 to 14 with highest values at the sedimentation peaks.

The proportion of PCAA-C of POC collected in sediment traps was $<5$ to $52 \%$ (Fig. 4). Highest proportions were measured at the sedimentation peak during the breakdown of the spring bloom (equivalent to $1.1 \mathrm{~g} \mathrm{AA}$ $\mathrm{m}^{-2} \mathrm{~d}^{-1}$ ) and at the sedimentation peak in mid-July $\left(0.38 \mathrm{~g} \mathrm{AA} \mathrm{m}^{-2} \mathrm{~d}^{-1}\right)$ due to rapid sinking of large diatoms.

In order to examine the significance of lake snow or POC losses by sedimentation we estimated the
Fig. 2. Percentage of total POC on lake snow from the end of March until October in 1993 in Lake Constance. Note that the value on 29 March is measured on a special type of aggregate directly at the surface

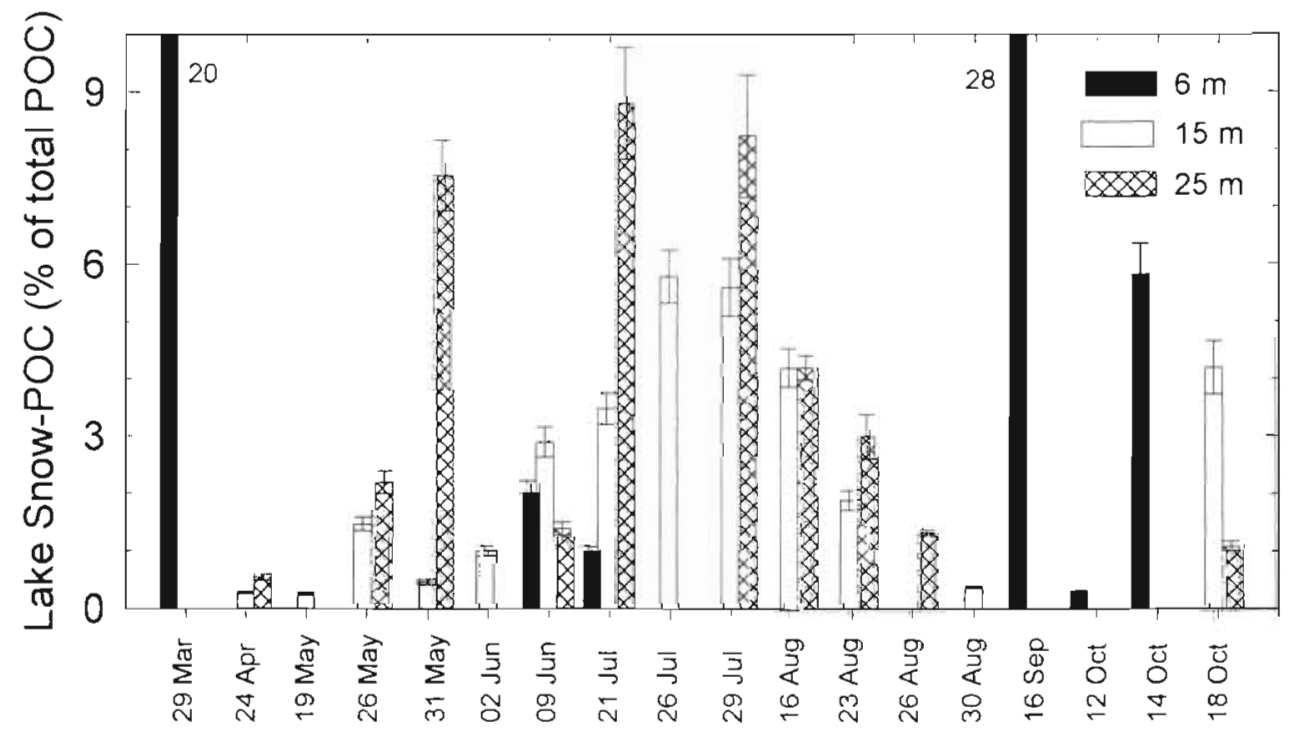




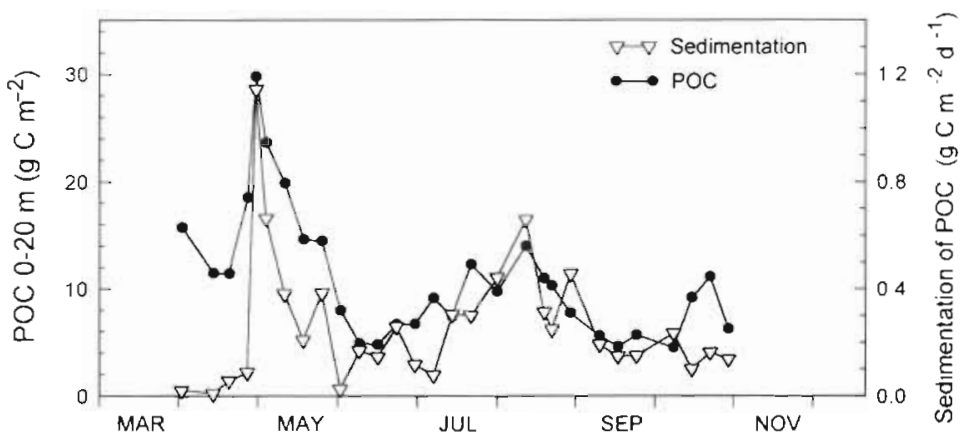

Fig. 3. POC integrated over the upper $20 \mathrm{~m}$ and sedimentation rates of POC from sediment trap material $(50 \mathrm{~m}$ ) in Lake Constance in 1993
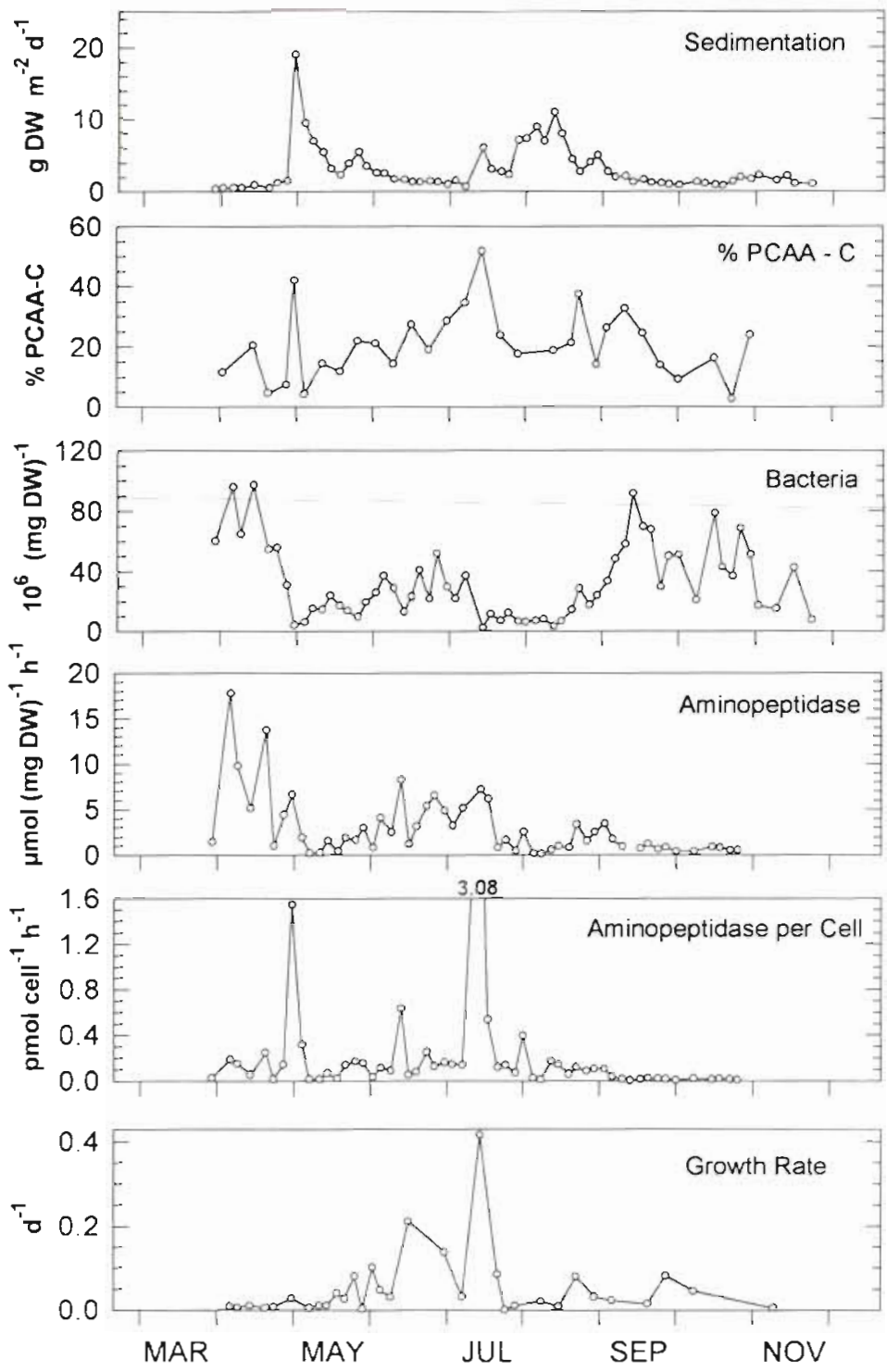

Fig. 4. Dry weight, percentage of PCAA-C of total POC, bacterial numbers, total and cell-specific hydrolysis rates of aminopeptidase, and bacterial growth rates of particulate matter collected in a sediment trap deployed at $50 \mathrm{~m}$ depth in Lake Constance in 1993 amount of $\mathrm{POC}$ bound in these aggregates which settled out of the upper $20 \mathrm{~m}$. These losses were calculated by the sedimentation rates of $\mathrm{POC}$ in aggregates and the potential sinking rates of lake snow (Table 1). We note that this calculation yields maximum sinking rates, and ambient rates presumably are somewhat lower. Losses of POC bound in lake snow were 0.14 to $11.1 \% \mathrm{~d}^{-1}$ (Table 2). Losses were high in June during the clear-water phase and highest in late July and August during the summer bloom. The comparison to total POC losses measured in sediment traps at $50 \mathrm{~m}$ shows that during the clear-water phase and the summer phytoplankton bloom losses by lake snow were relatively higher and even exceeded total losses of sinking POC (Table 2). Possible reasons why losses by aggregates exceeded those of POC are considered in the 'Discussion'.

\section{Bacterial colonization and decomposition of sediment trap material}

Bacterial numbers on sediment trap material were $<5$ to $100 \times 10^{6}$ cells $\mathrm{mg}^{-1} \mathrm{DW}$ (Fig. 4) Interestingly, they were highest when sedimentation rates were low like in early spring, in September, and in October. At the sedimentation peaks of the spring and summer phytoplankton bloom when POM settled rapidly bacterial numbers were low. During these periods high POC and PCAA concentrations in the sediment trap material were not reflected by enhanced bacterial numbers. Bacterial growth rates on settled PM were fairly low except in mid-June and midJuly when growth rates of 0.2 to $0.4 \mathrm{~d}^{-1}$ were measured simultaneously with high proportions of PCAA-C of total POC and with maximum cell-specific aminopeptidase activities (Fig. 4). At other times bacterial growth rates remained $<0.1 \mathrm{~d}^{-1}$.

Aminopeptidase activity of the sediment trap material was high in April before the spring bloom settled down and in June and July when bacterial numbers were enhanced as well (Fig. 4). At the sedimentation peak of the summer bloom in early August, however, aminopeptidase hydrolysis was very low. Cell-specific aminopeptidase activity showed 3 distinct maxima: at the sedimentation of the spring bloom (1.2 pmol 
Fig. 5. Time course of concentrations of dissolved free (DFAA) and combined amino acids (DCAA) at 1, 3.5, and $6 \mathrm{~cm}$ above sediment trap material: (A) deployment at $30 \mathrm{~m}$ depth and incubated ployment at $50 \mathrm{~m}$ and incubated in the lab at $4^{\circ} \mathrm{C}$ for 65 and $75 \mathrm{~h}$, respectively. All measurements were done in triplicates with a standard deviation $\leq 10 \%$ for 9 h in situ, ( $\mathrm{B}$ and $\mathrm{C}$ ) de-
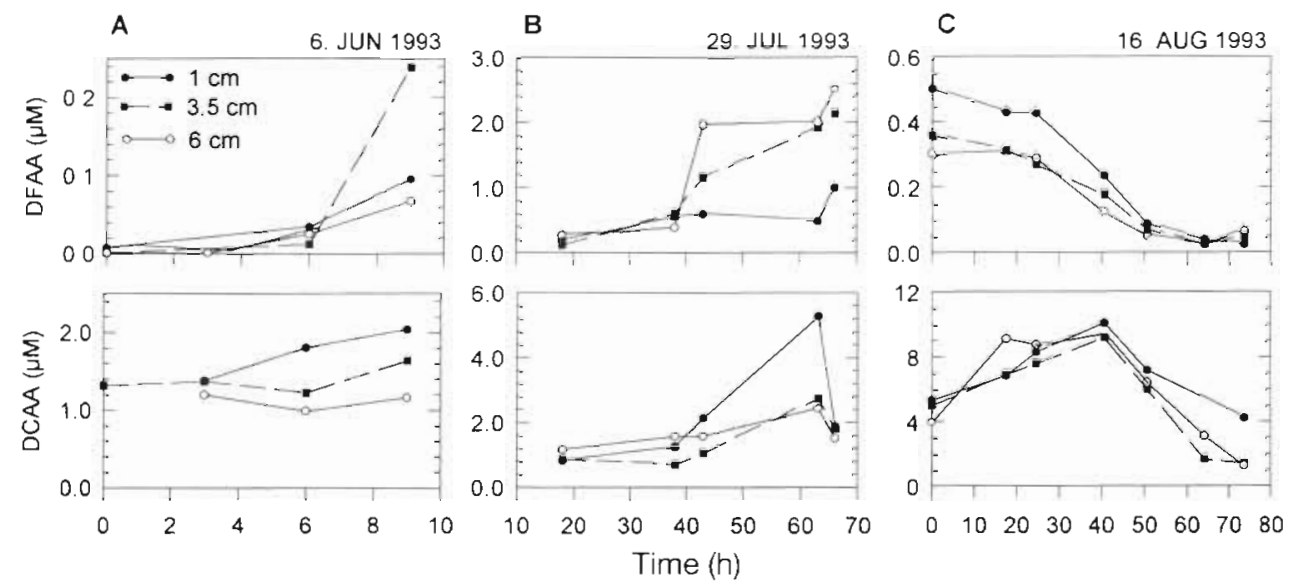

\section{DISCUSSION}

cell $\left.\mathrm{h}^{-1} \mathrm{~h}^{-1}\right)$, in June $\left(0.7 \mathrm{pmol}\right.$ cell $\left.^{-1} \mathrm{~h}^{-1}\right)$, and in midJuly (3.1 pmol cell ${ }^{-1} \mathrm{~h}^{-1}$ ) when the percentage of PCAA-C of the settled PM was high (Fig. 4).

On 3 instances we measured the concentration of amino acids in the overlying water of the settled PM over time. On 6 June during the clear-water phase changes in amino acid concentration were measured in situ (Fig. 5A). Within $9 \mathrm{~h}$ DFAA concentrations increased at $1,3.5$, and $6 \mathrm{~cm}$ above the collected material. DCAA concentrations exhibited a gradient from 1 to $6 \mathrm{~cm}$ but an increase in concentration was only detected at $1 \mathrm{~cm}$ from 3 until $9 \mathrm{~h}$. On 29 July, shortly after the first maximum of the summer bloom, changes in concentration of amino acids were measured in the lab at $4^{\circ} \mathrm{C}$ in the dark for $65 \mathrm{~h}$. During the initial $38 \mathrm{~h}$ DFAA concentrations only slightly increased at 1 and $3.5 \mathrm{~cm}$ whereas thereafter they strongly increased at 3.5 and $6 \mathrm{~cm}$ but remained constant at $1 \mathrm{~cm}$ (Fig. 5B). DFAA concentrations, however, in general were higher by 1 order of magnitude than in the previous experiment. DCAA concentrations also started to increase after $38 \mathrm{~h}$ but were highest at $1 \mathrm{~cm}$. At the end of the experiment after $62 \mathrm{~h}$ DCAA concentrations decreased again while those of DFAA still increased. On 16 August, $1 \mathrm{wk}$ after the sedimentation peak of the summer bloom, DFAA concentrations in our experiment in the lab showed a strong gradient from 1 to $6 \mathrm{~cm}$ until $40 \mathrm{~h}$ and decreased at all 3 layers over time (Fig. 5C). In contrast, DCAA concentrations increased until $18 \mathrm{~h}$ at all layers and further until $40 \mathrm{~h}$ at 1 and $3.5 \mathrm{~cm}$. Thereafter, concentrations decreased continuously until the end of the experiment.

In addition to these experiments we always found a strong gradient of dissolved amino acids in the water overlying the settled PM in freshly retrieved sediment traps (data not shown). On these occasions we also found a pronounced gradient of DCAA concentrations above the settled PM.
Our results show that the seasonal and vertical dynamics of lake snow are closely related to the occurrence of phytoplankton blooms in spring, summer, and fall and to losses of zooplankton due to sedimentation during the clear-water phase. During phytoplankton blooms lake snow constituted only a minor fraction of total POC but relative fractions increased with depth. This may imply that lake snow was relatively unimportant for the fluxes of elements and energy in the pelagic zone of Lake Constance and possibly other lakes. With respect to the transfer of energy and organic $C$ within the planktonic food web this is certainly true (Gaedke \& Straile 1994). With respect to the decomposition of sinking POM, however, the provide good evidence that lake snow is an important site for the decomposition of labile organic matter and constitutes a major fraction of the POC sinking flux. Export from the upper $20 \mathrm{~m}$ accounts for an annual mean of $20 \%$ of total epilimnetic POC losses in Lake Constance and for higher percentages during phytoplankton blooms (Stabel 1985), and therefore export is an important sink of epilimnetic POC. Lake snow, due to its relatively high sinking speed, is continuously removed vertically from the layer of its formation, mainly the epilimnion. We roughly estimated that lake snow contributed $\leq 20 \%$ to the total sinking loss of POC during the spring bloom and to higher proportions during the clear-water phase in late May and June (Table 2). Our estimates of the partitioning of lake snow to the POC sinking flux in summer were much higher, even exceeding the total sinking losses of POC. Even though this finding appears surprising, similar high estimates are reported by Alldredge (1979) and Alldredge \& Gotschalk (1989). On the basis of size, porosity, and density these authors calculated sinking rates of marine snow and estimated that its sinking flux in results presented here and in Grossart \& Simon (1998) 
the Gulf of California and the Santa Barbara Channel of the Southern California Bight (USA) highly exceeded the total sinking flux of POC. Marine snow in these environments comprised up to $64 \%$ of total POC. We want to point out that such estimates represent the maximum potential vertical flux of aggregates because they are based on their sinking rates which are determined experimentally or calculated with theoretical assumptions. The ambient partitioning of macroscopic organic aggregates to the POC sinking flux presumably is lower because their in situ sinking rates are lower than the potential rates. Possible changes of aggregate size during transportation, changes of the viscosity throughout the water column, sampling of biased populations of aggregates, and additional errors in the measurements of the sinking speed might have led to an overestimation of the actual sinking rate. Even though the sinking rates we determined experimentally are at the lower end of those determined for marine snow in various ways (Alldredge \& Silver 1988, Alldredge \& Gotschalk 1989, Newton et al. 1994), in situ sinking rates of aggregates presumably are still lower, thus leading to more realistic proportions of the contribution of large aggregates to the sinking flux. Turbulence, Langmuir circulations (Craik \& Leibovich 1976), and advective shear at the thermocline due to seiching may extend the residence time of these aggregates in the mixed layer. In addition, the sinking flux of aggregates below the thermocline may also be reduced by their consumption by zooplankton (Lampitt et al. 1993), fish (Larson \& Shanks 1996), and microbial decomposition (Smith et al. 1992. Hoppe et al. 1993, Grossart \& Simon 1998). Furthermore, the different techniques used integrate over different time intervals during which sinking rates of lake snow and of total POC could have changed.

On the other hand, decomposition of total POC during sinking and of sediment trap material during deployment may result in underestimation of the total POC sinking flux. Gries (1995) examined the decomposition of sinking particulate organic nitrogen (PON) in. Lake Constance in August with sediment traps at 16 and $50 \mathrm{~m}$ and found a loss of $40 \%$ of PON during $3 \mathrm{~d}$ of deployment. This indicates that PON is decomposed Iapidly and is consistent with our finding of a rapid PCAA turnover of aggregates and of sediment trap material (see below). Even though POC may not be decomposed as rapidly as PON, its decay during sinking leads to underestimation of total POC losses by sinking out of the epilimnion. Gries (1995) also estimated a sinking rate of tota. POC at $50 \mathrm{~m}$ of $<13 \mathrm{~m} \mathrm{~d}^{-1}$ and a mean of $3.7 \pm 2.9 \mathrm{~m} \mathrm{~d}^{-1}$ during the growing season in 1993. If this number is also representative for the epilimnion it illustrates that the sinking rate of lake snow is substantially higher and supports our finding that these aggregates are an important and in certain events the dominant fraction of the POC sinking flux

While sinking through the hypolimnion, lake snow is transformed and decomposed. This is indicated by our results on the colonization, growth, and hydrolytic activity of microbes on aggregates (Grossart \& Simon 1998) and on the material collected in sediment traps. We focussed our studies on the decomposition of PCAA which mainly comprise particulate proteins because they are the dominating biopolymers of the plankton biomass. Therefore, proteins are also a major fraction of the POM in the euphotic zone of pelagic ecosystems, comprising $>50 \%$ of $\mathrm{POM}$ in marine (Cowie \& Hedges 1992) and in lacustrine ecosystems such as Lake Constance (Rausch 1987). In our sediment traps PCAA-C comprised $<10$ to $45 \%$ of POC. Highest relative proportions occurred at sedimentation peaks at the end of the spring bloom and early in the summer bloom when presumably relatively fresh material rapidly settled down. All these values, however, are lower than the percentages of PCAA-C of $P O C$ on lake snow at 6 to $25 \mathrm{~m}$ and lower than that of protein of POM in the epilimnion in Lake Constance at the respective phytoplankton blooms (Rausch 1987). These observations indicate that PCAA are decomposed and hydrolyzed relatively faster than total POC while POM and aggregates are sinking through the hypolimnion. This notion is also consistent with the reduced fraction of $\mathrm{PON}$ and PCAA relative to POC in sediment trap material of different depths in Lake Constance (Gries 1995) and in marine systems (Wakeham et al. 1984, Cowie \& Hedges 1992).

Interestingly, at the sedimentation peaks of the spring bloom and the first peak of the summer bloom the sediment trap material was only sparsely colonized by bacteria. This is a further indication that this material was fairly fresh so that aggregate-associated bacteria, due to their low growth rates (Fig. 4), did not reach higher numbers. In contrast, at times of low sedimentation rates like in early April, September, and October, when presumably much older material reached the sediment traps, bacterial numbers on the settled material were substantially higher but bacterial growth rates were in the same range. The hydrolysis rate of the aminopeptidase, measured as $V_{\text {max }}$ did not consistently covary with enhanced PCAA proportions even though the activity was also enhanced at higher proportions. Interestingly, highest aminopeptidase activity occurred in early April when bacterial numbers were highest but PCAA proportions of POC in sediment traps relatively low. On the other hand, highest cell-specific aminopeptidase activity occurred simultaneously with the distinct peaks of the relative PCAA. proportions of $P O C$ but also together with very low bacterial numbers. These cell-specific rates were up to 
$10 \times$ higher than rates of aggregateassociated bacteria at 15 and $25 \mathrm{~m}$ in Lake Constance (Grossart \& Simon 1998) but were in the same range of aggregate-associated bacteria during the breakdown of a dense diatom bloom in a tank experiment (Smith et al. 1995) and by 2 orders of magnitude higher than on marine snow in the Northern Adriatic Sea (Karner \& Herndl 1992). This comparison indicates that potential aminopeptidase hydrolysis rates of bacteria attached to the sediment trap material is substantially higher than of bacteria on younger ( 1 to several days) lake snow collected 25 to $35 \mathrm{~m}$ above. Those high cell-specific hydrolysis rates further suggest that PCAA of lake snow and POM several days old, such as the material collected in the traps, are rapidly hydrolyzed. This suggestion is consistent with the enhanced PON loss relative to POC in sinking POM (see above) and the net release of dissolved amino acids (see below).

Even though a high cell-specific hydrolysis potential may imply that the ambient hydrolysis rates are comparably high, this may not necessarily be the case. We measured the aminopeptidase hydrolysis at saturating concentrations of the added substrate but ambient substrate concentrations presumably were lower and thus ambient hydrolysis rates as well. To calculate the turnover time of lake snow PCCA we assumed that DCAA were the only substrate for the aminopeptidase. On the basis of this and of DCAA concentrations in the matrix water of lake snow of 8 to $18 \mu \mathrm{M}$ (amino acid equivalents), PCAA turnover times of $<20 \mathrm{~h}$ were calculated. Since not all DCAA may be true substrates for the aminopeptidase and other peptidases hydrolyze DCAA as well, somewhat longer PCAA turnover times can be expected. We did not measure DCAA concentrations in the pore water of $P M$ in sediment traps. However, we can estimate the PCAA turnover of the PM in sediment traps on the basis of $V_{\max }$ of aminopeptidase hydrolysis rates (Fig. 4), the PCAA content of PM, and assuming that the DCAA concentrations in the pore water are similar to that in the matrix water of aggregates. The calculated PCAA turnover time in the sediment traps is in the same range as that of aggregate PCAA (a few days). These estimates indicate that PCAA are decomposed in a similar way on both types of POM and thus suggest that most of the PCAA of sinking POM is decomposed before it reaches the lake bottom.

A further indication of a rapid tumover of PCAA on sinking POM and PM in the sediment traps is the measured net release of dissolved amino acids from aggregates (Grossart \& Simon 1998) and from freshly collected PM in sediment traps (Table 3). These results are consistent with similar findings on marine snow (Smith et al. 1992). Because amino acids were released into the overlying water, which also contained growing bacteria consuming amino acids, the total release was presumably much higher than the changes in amino acid concentration indicate. On 29 July concentrations of DFAA were lowest but of DCAA highest at $1 \mathrm{~cm}$ above the PM, which indicates an effective uptake of DFAA by bacteria in the overlying water. These observations imply that sinking POM acts as a source of amino acids for free-living bacteria in the hypolimnion. In fact we observed enhanced concentrations of DCAA in the hypolimnion at the end of the clear-water phase and of the phytoplankton bloom in late July (data not shown), suggesting that pulses of sinking POM were the sources. In contrast, at the end of the summer bloom in mid-August, bacteria on the sediment trap material took up DFAA from the overlying water and increased DCAA concentrations only occurred for $40 \mathrm{~h}$ whereas thereafter even DCAA concentrations decreased, e.g. DCAA were taken up. These results indicate that sinking POM is not always a source of dissolved amino acids for the surrounding water but may also act as a sink. We cannot rule out the possibility that bacteria in the surrounding water took up amino acids. However, because of the low abundance of freeliving bacteria in the hypolimnetic waters and the low temperature we assume that these bacteria took up only a small fraction of the amino acids, if any. Decreasing ratios of POC:particulate phosphorus with increasing depth in the hypolimnion indicating fluxes from the dissolved to the particulate phase have already been reported by Gächter \& Mares (1985). We want to point out that this finding complicates the 1-way concept of bacterially mediated interactions between POM and DOM introduced by Azam \& Smith (1991). Our findings indicate that older POM deprived of labile organic matter such as at the very end of or after phytoplankton blooms may also take up amino acids from the surrounding water if available. Such a process may be important in certain situations to draw 
down labile DOM from the aphotic and possibly also from the euphotic water column. In such situations bacteria which colonize substrate-poor POM or aggregates may take advantage of sinking POM to scavenge substrates from the surrounding water and enrich POM with labile organic compounds. Large aggregates which exhibit a fractal geometry with a high surface area (Logan \& Wilkinson 1990) and thus a high adsorption potential may adsorb phosphate (Gächter \& Mares 1985), amino acids, and proteins (Kirchman et al. 1989). This mechanism may help to supply heterotrophic metazoans with nutrients further down in the water column or at the sediment surface.

\section{Conclusions}

Our study shows that lake snow is an important component of the POM sinking flux and that the microbial hydrolysis and dissolution of PCAA on sinking POM is an important process of POM decomposition below the thermocline in Lake Constance. It may be one of the major pathways supplying planktonic bacteria in these depths with dissolved amino acids when the lake is thermally stratified, and in particular during the sedimentation of large amounts of relatively fresh POM and lake snow such as during phytoplankton blooms. Our findings further provide evidence that lake snow plays a role in the POM sinking flux similar to that of marine snow. The presented results also suggest a second scenario which is relevant to marine snow as well for times when sinking POM is deprived of labile substrates and inorganic nutrients. In such situations bacteria attached to sinking POM scavenge dissolved amino acids and possibly other labile substrates and inorganic nutrients from the surrounding water and act as a sink. Situations like this are conceivable for periods after phytoplankton blooms and when DOM due to downwelling or lateral advection may reach deep layers in the aphotic zone of large lakes and marine environments

Acknowledgements. We thank $\mathrm{T}$ Gries, M. Decker, and $\mathrm{H}$ Wiedemann for their invaluable help in sampling on board We also appreciate valuabie comments and suggestions un an earlier version of this manuscript from 3 anonymous reviewers. This work was carried out as part of the Special Collaborative Program 'Cycling of Matter in Lake Constance (Bodensee)' funded by the Deutsche Forschungsgemeinschaft.

\section{LITERATURE CITED}

Aksnes DL, Wassmann P (1993) Modelling the significance of zooplankton grazing for export production. Limnol Oceanogr 38:978-985
Alldredge AL (1979) The chemical composition of macroscopic organic aggregates in two neritic seas. Limnol Oceanogr 24:855-866

Alldredge AL, Gotschalk CC (1989) Direct observations of the mass flocculation of diatom blooms: characteristics, settling velocities and formation of diatom aggregates. Deep Sea Res 36:159-171

Alldredge AL, Silver MW (1988) Characteristics, dynamics and significance of marine snow. Prog Oceanogr 20:41-82

Azam F, Smith DC (1991) Bacterial influence on the variability in the ocean's biogeochemical state: a mechanistic review. In: Dumers $\mathrm{S}$ (ed) Particle analysis in oceanography. Nato ASI Series 27, Springer-Verlag, Heidelberg, p 213-236

Baines SB, Pace ML, Karl DM (1994) Why does the relationship between sinking flux and planktonic primary production differ between lakes and oceans? Limnol Oceanogr 39:213-226

Bishop JK, Collier RW, Kettens DR, Edmond JM (1980) The chemistry, biology, and vertical flux of particulate matter from the upper $1500 \mathrm{~m}$ of Panama Basin. Deep Sea Res 27a:615-640

Bloesch J, Bürgi HR (1989) Changes in phytoplankton and zooplankton biomass and composition reflected by sedimentation. Limnol Oceanogr 34:1048-1062

Bloesch J, Burns NM (1980) A critical review of sediment trap technique. Schweiz Z Hydrol 42:15-55

Cowie CL, Hedges JJ (1992) Sources and reactivities of amino acids in a coastal marine environment. Limnol Oceanogr 37:703-724

Craik AD, Leibovich S (1976) A rational model for Langmuir circulations. J Fluid Mech 73:401-426

Davoll PJ, Silver MW (1986) Marine snow aggregates: life history and microbial community of abandoned larvacean houses from Monterey Bay, California. Mar Ecol Prog Ser 33:111-120

Eisma D (1993) Suspended matter in the aquatic environment. Springer-Verlag, Berlin

Fowler SW, Knauer GA (1986) Role of large particles in the transport of elements and organic compounds through the oceanic water column. Prog Oceanogr 16:147-194

Gächter R, Mares A (1985) Does settling seston release soluble reactive phosphorus in the hypolimnion of lakes? Limnol Oceanogr 30:364-371

Gaedke U, Straile D (1994) Seasonal changes of the quantitative importance of protozoans in a large lake. An ecosystem approach using mass-balanced carbon flow diagrams. Mar Microb Food Webs 8:163-188

Gotschalk CC, Alldredge AL (1989) Enhanced primary production and nutrient regeneration within aggregated marine diatoms. Mar Biol 103:119-129

Gries T (1995) Phosphorus budget of the upper $20 \mathrm{~m}$ of Überlinger See (Lake Constance) with a special emphasis on sedimentation. PhD thesis, University of Constance (in German)

Grossart HP. Simon M (1993) Limnetic macroscopic orqanic aggregates (lake snow): occurrence, characteristics, and microbial dynamics in Lake Constance. Limnol Oceanogr 38:532-546

Grossart HP, Simon M (1998) Bacterial colonization and microbial decomposition of limnetic organic aggregates (lake snow). Aquat Microb Ecol 15:127-140

Grossart HP, Simon M, Logan BE (1997) Formation of macroscopic organic aggregates (lake snow) in a large lake: the significance of transparent exopolymer particles (TEP), phyto- and zooplankton. Limnol Oceanogr 42 (in press)

Güde H, Roßknecht H, Wagner G (1998) Anthropogenic impacts on the trophic state of Lake Constance during the 
20th century. Arch Hydrobiol Spec Ser Adv Limnol (in press)

Honjo S, Doherty KW, Agrawal YC, Asper VL (1984) Direct optical assessment of large amorphous aggregates (marine snow) in the deep ocean. Deep Sea Res 31:67-76

Hoppe HG, Ducklow H, Karrasch B (1993) Evidence for dependency of bacterial growth on enzymatic hydrolysis of particulate organic matter in the mesopelagic ocean. Mar Ecol Prog Ser 93:277-283

Hoppe HG, Sang-Jin K, Gocke K (1988) Microbial decomposition in aquatic environments: combined process of extracellular enzyme activity and substrate uptake. Appl Environ Microbiol 54:784-790

Jones $G$ (1979) A guide for estimating microbial numbers and biomass in freshwater. Freshwat Biol Assoc Sci Publ 19

Karner M, Herndl GJ (1992) Extracellular enzymatic activity and secondary production in free-living and marinesnow-associated bacteria. Mar Biol 113:341-347

Kirchman DL, Henry DL, Dexter SC (1989) Adsorption of proteins to surfaces in seawater. Mar Chem 27:201-217

Lampitt RS, Wishner KF, Turley CM, Angel MV (1993) Marine snow studies in the northeast Atlantic Ocean: distribution, composition, and role as food source for migrating plankton. Mar Biol 116:689-702

Larson ET, Shanks AL (1996) Consumption of marine snow by two species of juvenile mullet and its contribution to their growth. Mar Ecol Prog Ser 130:19-28

Logan BE, Passow U, Alldredge AL, Grossart HP, Simon M (1995) Rapid formation and sedimentation of large aggregates is predictable from coagulation rates (half-lives) of transparent exopolymer particles (TEP). Deep Sea Res 42:203-214

Logan BE, Wilkinson DB (1990) Fractal geometry of marine snow and other biological aggregates. Limnol Oceanogr 35:130-136

Newton PP, Lampitt RS, Jickells TD, King P, Boutle C (1994) Temporal and spatial variability of biogenic particle fluxes during JGOFS Northeast Atlantic process studies at $47^{\circ} \mathrm{N}$, $20^{\circ}$ W. Deep Sea Res 41:1617-1642

Pomeroy LR, Hanson RB, Mc Gillivary PA, Sherr BF, Kirchman D, Deibel D (1984) Microbiology and chemistry of fecal products of pelagic tunicates: rates and fates. Bull Mar Sci 35:426-439

Porter KG, Feig YS (1980) The use of DAPI for identifying and counting aquatic microflora. Limnol Oceanogr 25:943-948

Editorial responsibility: Karel Simek

Ceske Budéjovice, Czech Republic
Rausch T (1987) The seasonal pattern of the biochemical composition of phytoplankton and seston in Lake Constance. PhD thesis, University of Freiburg (in German)

Riebesell U (1991) Particle aggregation during a diatom bloom. II. Biological aspects. Mar Ecol Prog Ser 69: 281-291

Shanks AL, Trent D (1979) Marine snow: microscale nutrient patches. Limnol Oceanogr 24:850-854

Simon M, Azam F (1989) Protein-content and protein synthesis rates of planktonic marine bacteria. Mar Ecol Prog Ser 51:201-213

Simon M, Lenhard A, Tilzer MM (1993) Bacterial production and the sinking flux of particulate organic carbon in a large and deep lake in comparison to oceanic environments. Mar Microb Food Webs 7:161-176

Simon M, Rosenstock B (1992) Carbon and nitrogen sources of planktonic bacteria in Lake Constance studied by the composition and isotope dilution of intracellular amino acids. Limnol Oceanogr 37:1496-1511

Silver MW, Alldredge AL (1981) Bathypelagic marine snow: deep-sea algal and detrital community. J Mar Res 39: 501-530

Smith DC, Simon M, Alldredge AL, Azam F (1992) Intense hydrolytic enzyme activity on marine aggregates and implications for rapid particle dissolution. Nature 359: $139-142$

Smith DC, Steward GF, Long RA, Azam F (1995) Bacterial mediation of carbon fluxes during a diatom bloom in a mesocosm. Deep Sea Res 42:75-97

Stabel HH (1985) Mechanisms controlling the sedimentation sequence of various elements in prealpine lakes. In: Stumm W (ed) Chemical processes in lakes. J Wiley and Sons, New York, p 143-169

Velji MJ, Albright LJ (1986) Microscopic enumeration of attached marine bacteria of seawater, marine sediment, fecal matter, and kelp blade samples following pyrophosphate and ultrasound treatments. Can J Microbiol 32: $121-126$

Wakeham SG, Lee C, Farrington JW, Gagosian RB (1984) Biochemistry of particulate organic matter in the oceans results from sediment trap experiments. Deep Sea Res 31: $509-528$

Weilenmann U, O'Melia CR, Stumm W (1989) Particle transport in lakes: models and measurements. Limnol Oceanogr 34:3-18

Submitted: August 12, 1997; Accepted: January 9, 1998

Proofs received from author(s): April 28, 1998 